\title{
A case for organic indigenous Christianity: African Ethiopia as derivate from Jewish Christianity
}

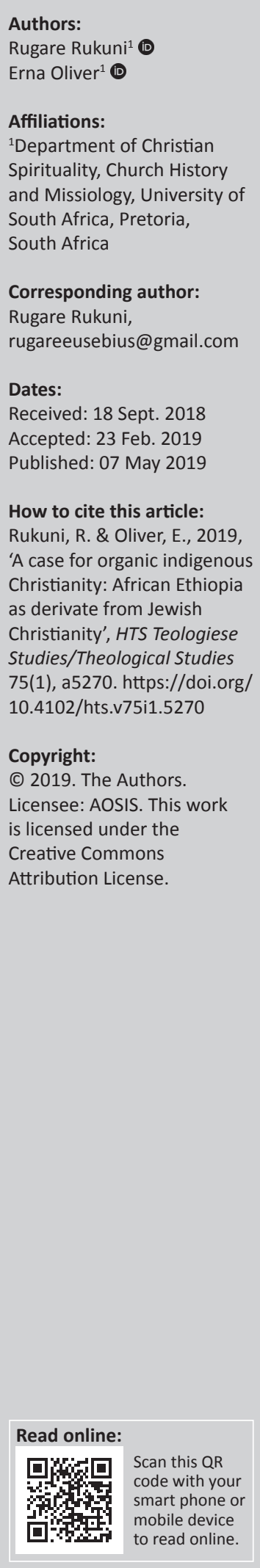

From its inception to the 4th century CE, Christianity experienced a formative process composite of three catalytic phases characterised by distinctive events (i.e. Jewish-Christian Schism, Hellenism and imperial intervention). From the aforementioned era emerged an orthodoxy fostered by an imperial-ecclesiastical link. There appears to have been a parallel story with regard to certain elements of African Christianity, in particular, Ethiopian Christianity. What can be made of the gap regarding Jewish Christianity combined with the absence of African Christianity from Bauer's modular theory on heresy and orthodoxy in the development of early Christianity? Despite the dominant story of the development of an imperial religious establishment at the turn of the 4th century, could there be an alternative narrative to Christianity in the African region derivate from Ethiopia? Reviewing the emergence of a religious political Christianity in this era as modular against Ethiopian Christianity in tangent with its links with Christianity in Roman Africa, establishment of the nature and development of Ethiopian Christianity was performed. This was performed through documentary analysis. Bauer's (1971) theory of orthodoxy and heresy in early Christianity did not exhaustively account for Jewish Christianity and North African distinct intransigent tradition characteristic of Carthage. By extension to African Egyptian, Alexandria is Ethiopian Christianity that was characterised by Judaic tradition in contrast to anti-Judaism. This established a parallel history of Christianity in Africa inclusive of Ethiopia. A review of this perspective contains contemporary momentum in view of the focus on Ethiopian Jews, for example, as religious praxis was as important as ethnicity in determining the Jewishness of whole tribes.

Keywords: North Africa; Indigenous Christianity; Jewish Christianity; Ethiopian Christianity; Church history.

\section{Introduction}

The Jewish-Christian schism came as a self-defining event in Christianity given the intrinsic Jewish origins of Christianity (Marcus 2012:87; Vermes 2012:27). The process of self-definition in the first 300 years of Christianity continued in a tri-sectorial phase. The tri-sectorial phase included the Jewish Christian schism, then Hellenism and ultimately the politics of Imperial intervention. This process witnessed the emergence of a form of Christianity metamorphised. After the Jewish Christian schism in the 2nd century, Hellenic philosophy gave its contribution to the emergent Christianity (Drodge 2012:231). Despite the fact that certain Judaic strands, such as the one in Alexandria, were Hellenised, Judaism and Hellenism, when reviewed as separate ideologies, had their distinct contribution upon Christianity (Lieu 2012; Marcus 2012; Nickelsburg 2003; Ruether 1996:31). Christian thinkers in this era, such as Justin, paralleled Christianity with ancient philosophy Dialogue with Trypho 2.1-2 (Schaff 1885a:305, 306). Ultimately, the political intervention of the Emperor Constantine and his promotion of Christianity witnessed the emergency of an aristocratic clergy coupled with a new form of orthodoxy (cf. Drake 2000). Of note was the antiJudaic tone of the Christianity then emergent (Nickelsburg 2003:196).

The self-definitive process became characteristic of much of Christianity in the Roman empire and outlived the imperial decline. There were Christianities, however, that had diverse elements from this 'universal or catholic faith'; to mention in Roman Africa, there were divergent elements such as in Carthage in the person of the Donatists (Edwards 2006:151; Frend 2012:522). While the current argument against this respective deficiency of Bauer's thesis has focused on Roman Africa or African Proconsularis, there were other African areas defiant of the Bauer theory (Decker 2015:11). Ethiopia or Axum, a geopolitical influence in the region, was Christianised in the 300s CE (Bowersock 2013; Isaac 2013). Derivate of its Judaic heritage and the inflow of Syrian Christians, it practised a Jewish-Christian faith (cf. Bowersock 2013). 
Ethiopia corresponds to the above-mentioned phenomenon as characteristic of its uniquely Jewish-like Christianity, which stands out against the common anti-Judaic faith. This I noted to be of significance with the resurgence of the debate concerning orthodoxy (Thompson 2015). The history of Ethiopian Christianity and its Judaic elements entails an introspection as to the definition of organic Christianity and concerning its connection with Jewish Christianity.

\section{Jewish Christianity or Judaic Christianity}

Since inception, Christianity by virtue of its origins in Israel had a Jewish connotation (Mitchell 2012:295). Given the complex Jewish religious-social matrix that is defined by a symbiotic blend of religious practice and ethnicity, the distinction between Judaism and Jewish is arguably a thin line (Lieu 2012:214). Correspondingly, this complicates the comprehension of the composition of Jewish Christianity or, alternatively, Judaic Christianity. Jewish Christianity has been characteristically deduced as the non-gentile practice of Christianity, alternatively, the Christianity that finds resonance with Torah and Jewish custom; this can be attributed to ethnically Jewish Christians (Marcus 2012:90). Correspondingly, the practice of this Jewish Christianity by non-ethnic Jews implies that this is a merger of Judaism and Christianity. The perceived merger is premised on the role of Judaism as praxis rather than ethnicity now embraced within Christianity by groups not essentially Jewish. In conformity with standard practice, the research will use the term 'Jewish Christianity'.

Jewish Christianity appears to have not been appreciated for its originality and possibly orthodoxy as an early practice of Christianity (Varner 2015). Thompson asserts a reconstruction of Bauer's (1971) thesis on heresy and orthodoxy in early Christianity (2015:213-214). The deductions from the present argument with regard to the deficiency of Bauer's theory on the phenomenon of Jewish Christianity pave the way for the discussion of Judaic forms of Christianity. Ethiopia, in particular, fits into this category. Research on Ethiopia in this perspective feeds into the current discussion about the Jewish-Christian schism. The vagueness surrounding the separation of Judaism and Christianity has premised the study of Jewish Christianity. It is against this background that the Ethiopian Christian narrative finds relevance, given the Judaic nature of its Christianity.

\section{The unclear border lines: Ongoing research on Jewish Christianity}

Varner (2015:89) observes what he calls the 'marginalisation of Jewish Christianity' amongst current early Christian scholarships. In the construct of Bauer's orthodoxy and heresy, the absence of this dynamic (Jewish Christianity), according to Varner, leaves a gap. Given the unclear influences upon regional North African Christianity in the first three centuries (Alexander \& Smither 2015:171-172), its distinct nature and intransigent autonomy (Tilley 2012:288), and given further consideration, a revision of Jewish Christianity and its connection to early African Christianity can be implied (Oden 2011:76-85). This being the established viewpoint regarding the gap in Bauer's theory, through the exclusion of African Christianity, by extension the investigation of Ethiopia, a Christianity under Jewish influences merits a revisionist approach to Bauer's theory.

First to enquire the possibility of Jewish Christianity and its influence upon early African Christianity and correspondingly Ethiopia poses relevance in the face of recent research establishing the existence of Jewish practising Christians in places such as modern-day Libya (Oden 2011: 76-85). According to Tilley, the origins of Christianity in the regions of North Africa argue for Semitic roots of Punic religion, which was a native outgrowth (2012:386).

In addition to the above, recent revision of the Jewish Christian schism entailed by the blurred lines of delineation as to what actually composes Jewish Christianity or Christianities (Jewish Christianity in its various forms), there is another substantiating factor (McCabe 2007:7-37). The author here mentioned rather an index of a general trend of revisionism to Yoder's (2003) construct of the Jewish Christian schism. The aforementioned revised approach emphasises the lack of clarity concerning the borderlines between the two institutes that parted ways (Judaism and Christianity) (Boyarin 2010:26, 27). If Jewish Christianity is itself ambiguous, how can a conclusion be made as to the nature of the Christianity that was in Ethiopia given its Semitic ties.

\section{The significance of the Jewish Christian schism in the self-definition matrix}

The origins of Christianity are Jewish (Vermes 2012:27). Christianity started in Palestine with a substantial Jewish composition of adherents. Marcus (2012:97) notes the resentment by some early Christian leadership of the way in which Christianity was heavily indebted to Judaism. Apart from the use of Jewish Torah, early Christian literature ran parallel to Jewish literature. For example, there are similarities between the Jewish apocalyptic documents and the interpretive dialogues in the Book of Visions (1.14.2; 2.4.1) (Schaff 1885b:13, 16).

The Jewishness of Christianity implies the significance of the Jewish Christian schism as a self-defining element in the trajectory of Christianity. As a culmination of Roman-Jewish hostilities and Jewish-Christian alienation, a schism emerged between Judaism and Christianity. While the specific timeline of when the schism rifted Christianity and Judaism can be debated to have been later centuries (Becker 2003:373-392; Boyarin 2010:6; Yoder 2003:43, 66), the general consensus is that the impact of the alienation was in the 1st century CE.

Lieu asserts that polemics between the two groups are evidence of a common matrix and the reality of an intentional separation: 'Jews and Christians share a common matrix even, or especially, when they refuse to acknowledge this' (2012:228). The Jewish Birkat haMinim [Blessing concerning the Heretics] and Justin's Dialogue with Trypho the Jew 
(Dial Trypho; Schaff 1885a:311) are an example of the alienating mindset that was existent in the two institutions in the 1st and 2 nd century CE. This mindset continued throughout the centuries as evident in the Christian literature and conciliar cannons (Pan Haer 30.4.1; Williams 2009:131; cf. Hist Eccl 5.23.2-3; Schaff 1885c:275). This characterised Christianity and became composite to its self-definition. It appears, however, that there was an exception with regard to North African Christianity and Ethiopia. Correspondent to the argument against Bauer's thesis, a review of North African Christianity as Christianity defined under unique influences relative to those in the rest of Roman Christendom will form the background to the investigation on Ethiopia.

\section{Parallels to Ethiopia: North African Christianity an anti-thesis}

The argument for the review of the Christian narrative with a focus on Ethiopia and its Judaic form of Christianity derives from the parallel development of North African Christianity and its Jewish-Semitic characteristics. Given the existent abundant scholarship on North African Christianity, such as Tilley (2012), Wilhite (2017), Alexander and Smither (2015), Davidson (2004), Edwards (2006) and others, North African Christianity is relatively traceable and decodable as compared to Ethiopian Christianity.

The comprehensively documented North African Christian narrative as a derivate from sources such as Tertullian, Cyprian and Augustine proves convenient in revising Bauer's thesis on orthodoxy and heresy. Therefore, the research here will comprehensively review North African Christianity against its divergence from Roman-Byzantine Christianity as a consequence of its Semitic links and distinct tradition. This respective section and review will serve as the background to the analysis of Ethiopian Christianity as correspondingly an extended argument against Bauer's thesis.

In line with the argument for basing the narrative of Ethiopian Christianity on the comprehensively documented history of North Africa, Wilhite argues for an African Christian narrative that recognises the ethnic and geographic dynamics that premised a distinct African narrative (2017:66). Geographically, Ethiopia cannot be said to have been detached from the events in Alexandria or the rest of Roman-Byzantine Christendom (cf. Bowersock 2013:93). This merits a review of Ethiopian Christianity against an African background.

The Jewish and Semitic contents of African Christianity become an argument for an evasion of this epoch -schism-in Christian history. In consideration of the formative nature of the Jewish-Christian schism, the suggestion that African Christianity was not exposed to this formative stage in early Christianity brings to view other implications.

If North African Christianity was not as exposed to the antiSemitic drive that fuelled the schism, it then remained Jewish or Hebraic in composition. This can be counterbalanced by some anti-Jewish literary works by Tertullian, a key African influence of Latin Christianity (Schaff 1885b:239). This can be overlooked given the evidence of Jewish or Semitic influence as already mentioned, such as in the Punic religion of the Berbers (Alexander \& Smither 2015:171-172; Tilley 2012:386). Arguably, this arises from the ambiguity concerning the origins of African Christianity (Davidson 2004:155), or rather the point of origin of African Christianity. The known records derived from martyrdom 180-202/203 CE point to these dates as the earliest account of North African Christianity (Alexander \& Smither 2015:169-170). One of these is the story of Perpetua (20.7; 21.8-10; Farina 2009:176; Musurillo 1972). This is not conclusive as to the non-existence of Christianity before these dates leaving room for an enquiry.

The ambiguity of the origins of North African Christianity and its Jewish nature implies the need to ascertain the possible existence of an organic Christianity in Northern Africa during the 1st century CE. The preceding argument is further substantiated by the organic and distinct nature of North African Christianity. The distinctness is evidenced by its identification with martyrdom and resistance, and unique cultural practice. Before discussing these below, a reconnection with the enculturation hypothesis further clarifies the matter.

As already ascertained, the schism was formative in the emergence of Christianity, primarily as an inciting element into the trajectory of alienation that would effect over the centuries. Setting the stage for the embrace of Hellenism in apology, the significance of the schism becomes emphasised for its place in the self-definitive continuum. When taken in a sociological or cultural historiographical review, the schism can be identified for its role in socio-ethnic dynamics and their interaction with religion and politics.

\section{First stage: Social dynamics - A schismatic element (the Christian-Jewish separation - The first stage of self-definition)}

The first stage of Christian self-definition witnessed the role of social ethnic elements in the form of hostilities that caused the schism (the Bar kosba uprising, Birkhat amminim, the polemics of Justin Martyr, erosion of Jewish Christianity) (Lieu 2012:214; Marcus 2012:101; Cassius Dio 68.32). This cleared the way for the second stage.

\section{Second stage: Syncretism - Hellenism (through the second Sophistic, Gnosticism, cultic process and emphasis upon homogeneity - the second stage of self-definition)}

The Jewish Christian schism did not seem to substantially impact North African Christianity; correspondingly, African Christianity would not be as Hellenised. The fact that North African Christianity found more regional influence than Graeco-Roman influence is another substantiation to this view, which will be reviewed briefly below. Added to this, its autonomous interaction with Roman imperial Christianity was possibly a consequence of this factor. This also raises the case for a comparison of Ethiopian Christianity as parallel to 
Graeco-Roman later turned Byzantine-Imperial Christianity. Ethiopian Christianity is riddled for its Hebraic Christian blend, with continuous research as to the actual source of this form of practice meriting further reviews.

\section{The organic nature of North African Christianity and its regional nucleus as influence}

The organic and distinct nature of North African Christianity as discussed above is further proof that anti-Judaic, proHellenic enculturation had not taken place, such as the rest of Roman Christianity. The Christianity of North Africa was just not Graeco-Roman (Alexander \& Smither 2015:171). The story of Carthage and the Donatist Controversy and how it played out was reflective of the martyr cult of North Africa and its intransigence against Rome (cf. Optatus Against the Donatists 3.3; Edwards 1997:62-68; Phillips 1917:59-70). This intransigence proved to be an inherent feature in the episcopal leadership of Cyprian and in his interaction with Rome (Epistles 50; cf. Brent 2009). Cyprian's creation of an ecclesiastical polity that was embraced into the conciliar culture that characterised imperial Christianity is notable as this proved somewhat the invincibility of these structures, even in the face of imperial persecution. This could have been a continuation of the independent ideology of Hannibal, who stood up to Roman domination, therefore being an icon of Carthagian independence, and also the Roman-Punic wars.

There is much evidence of how North African Christianity, especially in Carthage, made inroads through cultural and economic liaisons. The Donatists managed to enculture their form of Christianity amongst the marginalised Berbers (Roldanus 2006:175); given the hostilities between the Berbers and the Romans, the Punic-Semitic connection entailed strong sentiment against Rome and embrace of what would be native and organic practice of religion or tradition, which had been Judaised (Hull 2009:22, 23; Tilley 2012:386). It seems that the Donatist Christianity had managed to take the form of a national or patriotic orthodoxy movement, this establishment being resistant to the sweeping unity desired by the Emperor Constantine in the African church (Roldanus 2006:40).

The distinct nature of North African Christianity has been noted and established by substantial scholarship. Notable features characterising the African Christian narrative are a profound focus on martyrdom, tendency to be factious and schismatic, and a focus on conciliar decision-making (Sider 1971:15). In summary, I propose that this signifies the tradition of North African Christianity and that this also affirms the distinctive characteristic of North African Christianity to be a strong sense of tradition. This can explain the unique divergence of North African tradition from the ecumenical orthodoxy that gained prominence within the Constantinian era.

The emphasis upon tradition in North African Christianity would distinguish it from Roman Christianity that appears to have focused rather on figures, such as the bishop of
Rome (Hist Eccl 10.5; Schaff 1885c:608), which could be a reflection of the Dominate structure in the then newly acquired sole emperorship of Constantine (DMP 44.5-6; Schaff 1885f.:486-487; Lenski 2006:71, cf. Van Dam 2011). While Cyprian was instrumental in the creation of an ecclesiastical polity, it was conciliar politics that held authority in African Christianity (Unit Eccl 10-14; Schaff 1885e:744-746). The initial resistance to the emperor during the Decian persecution, having been entrenched in African martyr practice, entailed that the Church would autonomously interact with the empire and not be subject to external forces.

The cultural distinctness of North African Christianity and its resistance to the Roman Emperor can be evidence of failed Graeco-Roman enculturation. While, according to the model proposed, the culminated Christianity was significantly influenced by the imperial benefaction of Constantine in the 4th century $\mathrm{CE}$, the Christianity in this case was not as influenced. This further substantiates the model. The political component is the culminate phase of the enculturation of the Christianity that emerged in Rome as imperial Christianity or rather ecumenical orthodoxy (cf. Long 2013).

\section{Third- and final-stage: Political-Imperial intervention (that of the emperor, also a new dynamic of leadership: Imperial plus ecumenical polity)}

In the enculturation hypothesis, this is the third and final stage. As a result of the schism-Hellenisation, the politicisation of Christianity through the imperial link concludes the formative stages of ecumenical orthodoxy in the 4th century CE. Firstly, the seizure of the persecuting machine by the emperor made him a hero in Christianity - an ecclesiastical Moses-Eusebius (Hist Eccl 10.6; Schaff 1885d:613-614). The impact of this gave birth to an imperial propaganda (Cavanaugh 2013:85; Collier 2013:157).

In a policy for the promotion of Christianity, the emperor sponsored church building (Sozomen Hist Ecclest 1.5; Schaff 1885e:344-345; cf. Barnes 2011:111). Given the strength of the pagan traditions amongst the aristocracy, the emperor, it seems, was on a path of encouraging aristocratic conversion to Christianity (Salzaman 2002:198). The aforementioned dynamic was a reality although Christianity had many from the lower classes. A reconnection with the model implies the 4 th century as the era when there was political self-definition of Christianity. It has to be noted that this politicisation came as a convergence of imperial politics in the interests of Christianity and a firm structure of ecclesiastical leadership in the person of the monarchical bishopric Ignatius Letter to Smyrna 8.1 (Schaff 1885a:147).

It has to be noted that the system of ecclesiastical leadership had developed independently during the preceding three centuries. The system of ecclesiastical leadership came about as a result of the cultic process or intra-self-definition within Christianity (Meissner 2000:66). The merger of 
imperial politics with the episcopal establishment is what implied tangible political dynamics. Bishops were made 'conduits of imperial largesse' (Barnes 2011:133). In a worthy deduction:

1. Bishops were now entitled to quasi-judicial powers: there is abundant evidence that bishops presided over judicial cases, called the episcopalis audentia (bishop-overseen hearings), brought into the Roman judicial system (cf. Drake 2011; Van Dam 2011).

2. The emperor gave the council rulings a legally binding force (VC 4.27.2; Schaff 1885d:827-828), and he also sponsored the councils.

3. The emperor consolidated the authority of the metropolitan bishop by channelling the donations through them (Hist Eccl10.7.2; Schaff 1885d:614-615).

All of the above entailed the entrenchment of episcopal power giving birth to a phenomenon that was composite of these two arms, a religious political influence. The term 'imperial Christianity' has mostly been used to describe this political religious phenomenon that emerged at this point, and what I dubbed ecumenical orthodoxy.

The North African Church as established appeared as a radical non-compliant component to this emergent orthodoxy in 325 CE (Davidson 2004:154, 155). As already explored, this can be attributed to a multi-factorial theory. The main composition of this theory is the distinctness of African Christianity as a factor of greater regional enculturation relative to imperial Graeco-Roman enculturation. Secondly, it is the Jewish links that implied a Hebraic Christianity relative to Hellenised Christianity. Lastly, it is the intransigent nature of North African Christianity as personified in the martyr cult and strong systems of ecclesiastical leadership that autonomously engaged Rome. The aforementioned factors make North African Christianity a unique element unlike the then dominant orthodoxy of 325 CE. Notably, within an integrated narrative of North African Church history looms that of Ethiopia. Interestingly, Ethiopia is generally excluded from the geographical delineation of Christianity during Byzantine Rome; yet its narrative is indespensable for a comprehensive detailing of African Christianity.

\section{Ethiopia: The convergence of religious enculturation}

Ethiopian Christianity is a case in point. With regard to the distinguishing elements of African Christianity, the history of Ethiopian Christianity shows many relevant parallels.

The relevance of reviewing the history of Ethiopian Christianity just as that of North African Christianity or Jewish Christianity stems from the marginalisation of these studies from the mainstream theories. For example, as already established, North African Christianity was a missing element in the Bauer thesis of orthodoxy and heresy in early Christianity. In a corresponding evasion, the ambiguity concerning 'Jewish Christianity' entailed the many current reviews of it. Ethiopian Christianity for its antiquity has also entailed corresponding archaeological and historical enquiries.

I have deduced the value of a parallel study of Ethiopian history tangent to the Graeco-Roman ecumenical orthodoxy to stem from several aspects, most of which come as a derivation of its very nature:

1. The Ethiopian Jewish Links versus Roman Greco Ecumenical orthodoxy.

2. Ethiopian-clerical political relations against Romanclerical imperial traditions.

3. The influence of polity (bishops and emperors) in Roman Christianity against tradition in the Ethiopian church.

4. The Ethiopian resistance to the Catholic Portuguese or Spanish: a symbol of national traditional intransigence versus foreign imposed religious practice.

The above notes merit an application of the model derived in the review of Ethiopian history.

\section{The Ethiopian Jewish Links versus Roman Greco Ecumenical orthodoxy}

As established, the Christianity that had emerged from the Jewish Christian schism was Hellenistic enculturated. The enculturation of Hellenistic philosophy is a consequence of the cultural gap that emanated after the schism. The nature of Ethiopian orthodoxy is characterised by Judaic tendencies. This is evidenced by the observance of the Sabbath in a form of Hebraic strictness (Isaac 2013:28). There are other Ethiopian festivities such as the Fasika (Ethiopian festival of resurrection) that is a shadowy version of the Jewish Pesah (Isaac 2013:28). The Ethiopian Synaxarium's (a calendar of feasts and saints) narrative regards saints evidence a respectful tone with regard to Judaism, Jews or the Sabbath (Budge 2017). The preceding observation defines the distinct Hebraic nature of Ethiopian Christianity when the Ethiopian Synaxarium is juxtaposed with parallel literature in Roman-Byzantine Christianity, which would relatively project the anti-Judaism reflective of the formative Christian-Jewish schism.

The manner in which the churches of Ethiopian Tawahido Church were and are built reflects the temple of Solomon and its two apartments of the holy and the (most holy place) qidusta qiddusan (Ex 26:33, 1 Ki 6) (Isaac 2013:29). The story of the ark is also intricately attached to the succession legend of Ethiopian imperial polities as found in the Kebra Nagast [The Glory of the Kings]. In the legend, we establish that the ark of the covenant, the central feature of ancient Judaism, was supposedly brought to Ethiopia. The ark characterises the church structures of the Tawahido Churches. The Tabot (ark of the covenant) is just as key an icon as was the cross in western cathedrals (Friedlander \& Friedlander 2015:84). This serves to show the intrinsic Hebraic nature of the Christianity that was dominant in Ethiopia. Despite the aggregate comprehension regarding the Hebraic practices, particularly the Sabbath, there were instances where there was a challenge to this Judaic form of Christianity. 
In 14th-15th centuries CE, the Abuna [Bishop] diverged from the Negus [King] over the Jewish Sabbath, also evidently a matter that pitted the influential ascetics of Ethiopia against each other (Binns 2017:58). The sect of Ewostatewos, which was influential over the northern monasteries, regarded the sacredness of the Jewish Sabbath, while, in contrast, the house of Takla Haymonot that reflected the Alexandrian views advocated for Sunday sanctity (Binns 2017:58). The matter was resolved through a conciliar resolution overseen by the presiding Negus [King] Zar'a Ya'qob who reinforced the Sabbath, thereby mending the rift in the national Christianity (Binns 2017:58). The prevalence of Judaic practice is an aggregate deduction from this narrative, arguing indirectly for the entrenched Judaic religious enculturation in Ethiopian Christianity. The capacity of the Jewish form of Christianity to retain a nationalistic significance arguably entails an entrenched cultural practice of this respective religion perceived as organically native (cf. Roldanus 2006).

The origins of Ethiopian Christianity is a subject of great controversy, particularly in relation to where the Judaic practices emanated from. There is evidently strong tradition as chronicled in the Kebra Nagast (The Glory of the Kings); however, there has been some introspective enquiry from archaeology and anthropology (Phillipson 2012:102-103). Another issue raised as to the Judaic nature of Ethiopian Christianity is the probability of a contact or non-contact theory with Jews (Isaac 2013:31). Alternatively, there have been suggestions of dual conversion in sync with the legends found in the Kebra Nagast (The Glory of the Kings) and Rufinus and Theodoret's Histories. Under this perspective the first initial conversion of the nation was to Judaism and then later on to apostolic Christianity. A review of Ethiopian practices argues for a church that had strong praxis or tradition, something indeed akin to Judaism, but more distant from gentile Christianity. Despite the many propositions, the consensus is for a Christianity foreign to the Mediterranean practices.

Isaac asserts the influence of Syriac-Aramaic-speaking Jewish Christians rather than Greek-speaking Jews to have been the primary factor as to the Christianity of Ethiopia (Isaac 2013:36,37). This, he argues, was the trend since 70 CE when, with the destruction of Jerusalem, some Christians took refuge in Antioch. Evidence for this theory is the existence and preservation of Jewish Apocalyptic works such as the Book of Enoch and Jubilees, which also were used amongst Aramaic-speaking Jewish Christians - notably, these works were preserved in $G^{\prime} e z$ the language of literature in Ethiopia (Isaac 2013:36,37). This serves as a concluding fact that the nature of Christian influence upon Ethiopia was very Jewish. The existence of Jewish Christianity in myriads of forms, as already established, implies that what may not have been identified as such for lack of review could have in actual fact been Jewish Christianity.

\section{The strength of Hebraic tradition}

The intransigent indigenous nature of Ethiopian practices follows the narrative of the nation's history from antiquity throughout the medieval era and beyond. Paez's medieval first-hand accounts show resistance by the Ethiopian indigenous Christianity to Catholic theology on Christ, or rather a non-compliance to the widespread Nicene or Chalcedonian orthodoxy (Boavida, Pennec \& Ramos 2011:313, 321). As if this was not enough, Paez emphasised the Judaic practices of the Ethiopians, amongst these being circumcision and Sabbath keeping (Boavida et al. 2011:359). The fact that these identified the indigenous practice of the Ethiopian orthodox church versus the Roman Catholic faith that was represented by Pedro Paez has implications on the selfdefinitive aspects of Ethiopian Christianity. The Jewish practice in Ethiopian Christianity was Jewish-semitic and not organically indigenous to Ethiopia. This relates to the significance of Solomonic dynasty in the Ethiopian religious matrix and the possible regional influence upon Ethiopian religion. It is notable how the Hebraic traditions lived and live on despite the face-lift of the Ethiopian religious terrain through the invading influence of Islam (Hassen 2015), and to mention Catholicism and Coptic Christianity. This poses a sociological and anthropological question pertaining the enculturation and religion of Native Ethiopia.

Lalibela, a region surrounded by rock-hewn monolithic churches in Ethiopia, is amongst the ancient wonders of the world (Friedlander \& Friedlander 2015:263). Lalibela churches, such as the Yemrahane Krestos, are attributed to the Zagwe dynasty that reigned from 1140 to 1180 CE (Friedlander \& Friedlander 2015:263). The archaeology of Lalibela further argues for the strength of Jewish traditions. The complex of Lalibela was built as a symbolic new Jerusalem in the era when Jerusalem fell to Saladin during the crusades. Despite the evidence of internal assertion of legitimacy by King Lalibela by associating with the Solomonic descent, there is an argument for intrinsic strength of Jewish tradition (Phillipson 2012:238). The very names of the churches and areas have parallel with actual places in Palestine. The very design is a shadow of Jerusalem, for example, the mount of olives, the Jordan river (Finneran 2007:227).

Aggregately, Ethiopian Christianity that emerged was one that had tradition at its centre. This can be played against the religious political orthodoxy that emerged in $325 \mathrm{CE}$. It follows that Ethiopian Christianity in which tradition can be identified as formative dynamic is in contrast to RomanGreco Christianity in which politics was a formative element coupled with enculturation. As evidence, the interaction of the Ethiopian-clerical imperial polities shows the dominant role of tradition as superseding the preceding two factors. While the narrative of ecumenical orthodoxy shows the emergence of an integrated and encultured ecclesiastical political outfit, that of Ethiopian orthodoxy chronicles the resistance of an indigenous populus against certain imperial decisions to change the national practice of religion and adopt other faiths. A case in particular would be concerning the emperor Susenyos and his attempt to impose the Catholic faith upon the rest of the empire (Caraman 1985:80; Hassen 2015:276). 
The emperor Suseynos (1607-1632) came to power against rivalry. Added to the threat to his throne was the threat of the Muslim Oromo (Hassen 2015:306). So as to contain this threat, the emperor courted the help of the Catholic Portuguese and a policy of divide and conquer against the Oromo (Caraman 1985:80). This was mainly through the Catholic Conduit that was present in his palace: the Spanish Jesuit priest Paez (1603-1622) (Hassen 2015:307). Correspondence with Rome was successful with the promise, from the Pope, of military help from the Catholic Spanish King Philip. The acceptance and imposition of Catholicism entailed a need for military backup on the emperor's part such that there would be no opposition to his actions (Caraman 1985:94).

The implementation of Susenyos' new religious policy made him somewhat a reverse Constantine in his imposition of Catholicism. He was more of a persecutor of the indigenous orthodox Christianity of Ethiopia. In 1614, he embarked upon a policy of harassing the indigenous clergy with the intention of replacing them with Catholic institution (Boavida et al. 2011:242). The costly result of this was insurgence, revolts from his trusted officials, even relatives and the masses. Of note are the coalitions of the Muslim Oromo and the pursued Christians. This proved the nationalistic sentiment that was behind the resistance as more than religion that would imply a common cause but rather a commonality in tradition and practice.

\section{Ethiopian Christianity in context}

In the background of the era in which the emergence of a religious political orthodoxy emerged in Rome at Nicaea, there was the rise of a distinct Christianity so far removed from the Christianity that was conquering the empire. The rise of Christianity in Ethiopia in the 4th century CE implies another narrative in the development of early Christianity.

The shape and form of Ethiopian Christianity entails a parallel analysis to the emergence of Constantinian Imperial Christianity and ecumenical orthodoxy. This is apparent in the religious political nature of the form of Christianity then emergent. There appears to be an intricate attachment in the tradition that substantiated the monarchical authority and that which chronicles the advent and spread of Christianity in Ethiopia.

The history of this early form of Christianity ca. $300 \mathrm{CE}$ is patchy in terms of evidential material in the form of archaeology to be particular but is abundant for a latter chronological establishment (Phillips 2012:91). Also, the sources entailing a coherent record are external and from a later date. The accounts of Rufinus in his Ecclesiastical History and Theodoret in his Ecclesiastical History are notable derivate sources. In the aforementioned sources, the Christianisation of Ethiopia or its role in the Early Nicene Church does not take centre stage but rather serves as an extension of a survey of the widespread influence of the Alexandrian Bishop Athanasius. Hence, inferred documents of correspondence and the perceived view of the Ethiopian Christians by the
Alexandrian Athanasius and later George of Cappadocia will be reflective of the documents, dually the record of the Byzantine emperor's interaction with the monarchies.

Yet, the development of Ethiopian Christianity is composed of a narrative that equals that of Roman imperial Christianity and later on medieval Christianity in a parallel chronological comparison.

The origins of Ethiopian Christianity in the 4th century CE have to be established ontologically against the background of Christendom, that is, the narrative of Ethiopian Christianity in its conception should be reviewed with regard to the nature and form of Christian praxis; this should be accomplished in parallel reference to Roman-Byzantine Christianity. The 4th century being the dawn of a new orthodoxy (ecumenical orthodoxy) and an entrenched religious political system in Rome and later Constantinople (Wickman 2017:280) poses a self-definitive complexity with regard to the form and nature of the Christianity that characterised Ethiopia. Where did it stand with regard to the Nicene Creed $325 \mathrm{CE}$, or later the Chalcedonian $451 \mathrm{CE}$ solution regarding Monophysitism? While Ethiopian tradition concerning the interaction with the church came through the Alexandrian Patriarch, it appears Ethiopia had a level of autonomy (Isaac 2013:38, 39).

Possibly, the records that portray the substantial level of control by the Roman episcopal to see through Alexandria of Ethiopian affairs need a revisionist approach. The interaction of the emperors Julian (Byzantine) and Kaleb (Ethiopia) shows levels of equality rather than subordination (Phillipson 2012:204) (Procopius Wars I.19-20, Dewing 1914-1928:1:178195). The preceding analysis of the literature from this age of Christianity shows orthodox propaganda, at times reformulated histories in favour of the dominant ecclesiastical leaders (Ferguson 2005:24; Leithart 2010). An analysis of Eusebius, a chief source from this era, substantiates the view of the emergence of a pro-emperor and orthodoxy agenda. This to the point where even past events and personalities from the 1st century $\mathrm{CE}$ are painted with an impressionism that corresponded to the general mood of the 4th century CE, especially after the emperor's benefaction.

The history of Ethiopian religion is notable for its syncretistic nature. Archaeological evidence establishes the presence of polytheistic religions in the pre-Christian Aksumite Empire, that is, before the 4 th century CE. According to Phillipson (2012:91), linking Ethiopia, the southern horn and southern Arabian antiquity was the inscription of the crescent and disc symbol. These symbols in pre-Christian Aksumite Ethiopia appeared on coinage and on the edifices of the Anza and Matara stelae; these stelae have been dated to the 3rd century CE on palaeographic grounds (Phillipson 2009b:122).

\section{Unchanging traditions}

The resurfacing of these symbols upon buildings in the Christian era of the mid-4th century or, rather as established 
by Phillipson (2009a:43), the existence of non-Christian buildings during the underlined Christian era, has implications on the religion of Ethiopia and its enculturation. There is an archaeological argument that a chronological identification of infrastructure could imply inadequacies. I argue that the slightest hint of the existence of the traditional or indigenous religions of Ethiopia that imply a regional influence as evidenced by the inscriptions on the coinage and the stelae explains the generic influence of tradition in the religious matrix of Ethiopia. Retrospectively, because there is evidence of Judaic impressionism in the Ethiopian religious matrix, it must also be noted how Judaism intrinsically formed religious tradition in Ethiopia. The earlier history of Aksum during the BCE era, though derived from later evidence, establishes Jewish-Axum relations as ancient (cf. Friedlander \& Friedlander 2015).

The preceding parallels the entrenchment of pagan Roman tradition and their worship of their pantheon of gods, and how that was a determinant and formative factor in society. The influence and impact of this dynamic is perhaps comprehended in view of the divide between Licinius (AD 312-320) and Constantine. Constantinian religious policy, which promoted a trajectory towards Christian monotheism and departure from Graeco-Roman polytheism, courted public disgruntlement from members of the Roman Senate (aristocracy). This alienated Constantine from aristocrats while endearing them to Licinius, his coruler in the East (Milan) (Potter 2013:215; Eusebius, Lactantius). Constantine engaged in a policy of hostility towards paganism or polytheism while syncing the ecclesiastical polity into Roman power structures (cf. Barnes 2011:140; Roldanus 2006:71). Constantine gained through this the title Novator turbatorque priscarum legume et morisantiquitus recept $i$ [a wicked innovator and tamperer with the time-hallowed laws and the sacred ethical traditions of our fathers] - Alfodi (1969:31). It appears that the influence of entrenched tradition was a significant dynamic to consider when evaluating the political implications of imperial policy.

\section{The aristocracy as guardians of tradition}

The emperor, as a symbolic aristocrat by refusing to practise the traditional religions, made an indirect statement to the aristocracy as to the direction the empire was heading; a good example of this is Constantine's refusal to sacrifice to Jupiter on 28 October $312 \mathrm{AD}$ after entering Rome from the Milvian bridge experience (Potter 2013:145). This and the systematic elevation of Christian clergy through legislation; for one, the judicial magisterial role given to Bishops and their exemptions from secular courts in the year AD 355 (C.Th 16.2.12) (Barnes 2011), coupled with imperial prerequisites to high office, which would at times involve conversion to Christianity, influenced many aristocratic conversions (Salzaman 2002:181). This implied a change in the traditional or cultural practice of Roman politics, here personified in the Roman aristocrats (usually members of the senate). Consequently, this new dynamic meant the cultural transformation of Roman polity and the empire itself - a process in which a new type of empire emerged. There was, however, a counterdynamic to this phenomenon; one that I understand to have been a significant shaping factor in the manner and type of ecclesiastical polity that was to emerge.

There was substantial political interdependence between the emperor and the aristocracy (Salzaman 2002:188). This stemmed from several reasons intrinsically connected to the fact that the security and authority of the governing emperor lied in his relations with the Roman aristocracy. The preceding conclusion I made based, for example, on the fall of some of the most militarised emperors in Rome, the main example being Julius Caesar who, except for assassination by the arrangement of a clique in the Roman senate, appeared invincible as a war hero. Despite the Christian zeal or strong conviction for Christianising the empire as portrayed by Constantine, for example, there would be a check and balance in the person of the strongly pagan aristocrats. This ultimately implies the strength of cultural dynamics in the formation of orthodoxy or religious policy. Imperial influence could only go so far.

The connection between the aristocrats in the east where Licinius ruled and those in Constantine's court was very much an established reality (Potter 2013:215). Moreover, this connection took place with the background of a dynamic Constantine who refused to sacrifice to Jupiter upon his triumphal entry - this against a Licinius in the East who believed in the traditional gods of Rome. Possibly, those aristocrats in Constantine's court who were pro-pagan had a substantial reason for a conspiracy with Licinius, as suggested in Eusebius.

The preceding factor further entrenches the idea of the strength of cultural dynamics in shaping any religious political entity and how even the emperor was incapacitated. This explains, possibly, the deemed compromise of Constantine, such as the fact that there was never a church constructed in the midst of Rome. According to Kreider (2013:49), the religious and administrative centre of the empire was preserved for pagan monuments. This was possibly so as not to offend the pagan aristocracy. The aristocracy was inevitable for a successful political dispensation (Salzaman 2002:198).

\section{Conclusion}

A tangent review of Roman Greco Christianity and elements in North African Christianity argues the case for a distinct Christianity, one characterised by features removed from the events in Roman Greco Christianity. The centrality of tradition is a major catalyst. The Judaic elements serve to entrench the introspection into Afro-Semitics. These dynamics actually argue for a detailed parallel study of North African Christianity alongside Graeco-Roman Christianity. Despite the background that saw the emergence of an imperial-ecclesiastical orthodoxy, North African Christianity intransigently maintained distinct tradition. Ethiopian Christianity's connections with a Judaic 
pre-Christian era entail an enquiry of it as a contemporary of Nicene Christianity. Ethiopian Christianity's self-definition establishes the formative role of tradition. Therefore, there is a need for the establishment of a parallel chronology of the religion or Christianity of Ethiopia, spanning from its antiquity to the post-medieval era.

\section{Acknowledgements Competing interests}

The authors declare that they have no financial or personal relationship(s) that may have inappropriately influenced them in writing this article.

\section{Authors' contributions}

R.R. was the main author and performed the actual writing. E.O. was the guide and an advisor. Both the authors contributed equally to this work.

\section{References}

Alfodi, A., 1969, The conversion of Constantine and Pagan Rome, Oxford University Press, Oxford.

Alexander, D.C. \& Smither, E.L., 2015, 'Bauer's forgotten region: North African Christianity', in P.A. Hartog (ed.). Orthodoxy and Heresy in Early Christian Contexts: Reconsidering the Bauer Thesis, pp. 166-192, Pickwick Publications, Eugene, OR.

Barnes, T.D., 2011, Constantine. Dynasty, religion and power in the late Roman Empire, Wiley-Blackwell, Chichester.

Bauer, W., 1971, Orthodoxy and Heresy in Earliest Christianity, 2nd edn., Fortress, Philadelphia, PA.

Becker, A.H., 2003, 'Beyond the spatial and temporal limes: Questioning the "parting of ways" outside the Roman Empire', in A.H. Becker \& A.Y. Reed (eds.), The ways that never parted: Jews and Christians in late antiquity and the early middle ages, that never parted: Jews and Christians
pp. 373-392, Mohr Siebeck, Tübingen.

Binns, J., 2017, The orthodox church of Ethiopia: A history account, I.B. Tauris, London.

Boavida, I. \& Pennec, H. \& Ramos, M.J. (eds.), 2011, Pedro Paez's History of Ethiopia, 1662,2 vols, The Hakluyt Society, London.

Bowersock, G.W., 2013, The throne of Adulis: Red Sea Wars on the Eve of Islam, Oxford University Press, New York.

Brent, A., 2009, A political history of early Christianity, T \& T Clark, New York.

Boyarin, D., 2010, 'Judaism as a Free Church: Footnotes to John Howard Yoder's The Jewish-Christian schism revisited', in P. Dula \& C.K. Huebner (eds.), The New Yoder, pp. 1-17, Cascade Books, OR.

Budge, E.A., 2017, Synaxarium: The book of the saints of the Ethiopian orthodox Tewahedo Church, Ethiopian Orthodox Tewahedo Debre Meheret St. Michael Church, Garland, TX.

Caraman, P., 1985, The lost empire: The story of the Jesuits in Ethiopia 1555-1634, University of Notre Dame, Notre Dame, IN.

Cavanaugh, W.T., 2013, 'What Constantine has to teach us', in J.D. Roth, (ed.). Constantine revisited: Leithart, Yoder, and the Constantinian debate, pp. 83-100 Pickwick Publications, Eugene, OR.

Collier, C.M., 2013, 'Leithart's defending Constantine: A review', in J.D. Roth (ed.), Constantine revisited: Leithart, Yoder, and the Constantinian debate, pp. 155-160, Pickwick Publications, Eugene, OR.

Davidson, I.J., 2004, The birth of the Church: From Jesus to Constantine, A.D. 30-312, Monarch Books, Oxford.

Decker, R.J., 2015, 'The Bauer thesis: An overview', in P.A. Hartog (ed.), Orthodoxy and Heresy in Early Christian Contexts: Reconsidering the Bauer thesis, pp. 6-34, Pickwick Publications, Eugene, OR.

Dewing, H.B., (ed. \& trans.), 1914-1928, Procopius: History of the Wars, Heinemann (Loeb Classical Library), London.

Drake, H.A., 2000, Constantine and the Bishops: The politics of intolerance, Johns Hopkins University Press, Baltimore, MD.

Drodge, A.J., 2012, 'Self-definition vis-à-vis the Greco-Roman world', in M.M. Mitchell \& F.M. Young (eds.), The Cambridge History of Christianity: Origins to Constantine, pp. 230-245, Cambridge University Press, New York.

Edwards, M., 1997, Optatus: Against the Donatists, Liverpool University Press, Liverpool.

Edwards, M., 2006, 'The beginnings of Christianization', in N. Lenski (ed.), The Cambridge companion to the age of Constantine, pp. 137-158, Cambridge University Press, New York.
Farina, W., 2009, Perpetua of Carthage: Portrait of a third-century Martyr, McFarland, Jefferson, MI.

Ferguson, T.C., 2005, 'The past is prologue: The revolution of Nicene Historiography', in J. Den Boeft, J. Van Oort, W.L. Petersen, D.T. Runia, C. Scolten \& J.C.M. Van Winden (eds.), Supplements to Vigilae Christianae (Formely Philosophia Patrum) texts and studies of Early Christian life and language, Brill, Leiden.

Finneran, N., 2007, The archaeology of Ethiopia, Routledge, London.

Frend, W.H.C., 2012, 'Persecutions: Genesis and legacy', in M.M. Mitchell \& F.M. Young (eds.), The Cambridge History of Christianity: Origins to Constantine, pp. 503-523, Cambridge University Press, New York.

Friedlander, M. \& Friedlander, B., 2015, Hidden treasures of Ethiopia: A guide to the remote churches of an ancient land, I.B. TAURIS, London.

Hassen, M., 2015, The Oromo and the Christian Kingdom of Ethiopia 1300-1700, James Currey, New York.

Hull, R., 2009, Jews and Judaism in African history, Markus Wiener, New Jersey.

Isaac, E., 2013, The Ethiopian Orthodox Tawahido Church, The Red Sea Press, New Jersey.

Kreider, A., 2013, '“Converted" but not Baptised: Peter Leithart's Constantine project', in J.D. Roth (ed.), Constantine revisited: Leithart, Yoder, and the Constantinian in J.D. Roth (ed.), Constantine revisited: Leithart, Yoder,
debate, pp. 25-67, Pickwick Publications, Eugene, OR.

Leithart, P.J., 2010, Defending Constantine: The twilight of an Empire and the Dawn of Christendom, InterVarsity Press, Downers Grove, IL.

Lenski, N., 2006, 'The reign of Constantine', in N. Lenski (ed.), The Cambridge companion to the age of Constantine, pp. 59-90, Cambridge University Press, New York.

Lieu, J., 2012, 'Self-definition vis-à-vis the Jewish matrix', in M.M. Mitchell \& F.M. Young (eds.), The Cambridge History of Christianity: Origins to Constantine, $\mathrm{pp}$. 214-230, Cambridge University Press, New York.

Long, D.S., 2013, 'Yoderian Constantinianism', in J.D. Roth (ed.), Constantine revisited: Leithart, Yoder, and the Constantinian debate, pp. 100-124, Pickwick Publications, Eugene, OR.

Marcus, J., 2012, 'Jewish Christianity', in M.M. Mitchell \& F.M. Young (eds.), The Cambridge history of Christianity: Origins to Constantine, pp. 87-103, Cambridge University Press, New York.

McCabe, M.A.J., 2007, Jewish Christianity reconsidered: Rethinking ancient groups and texts, Fortress Press, Minneapolis, MN.

Meissner, W.W., 2000, 'The Cultic origins of Christianity: The dynamics of religious development, The Liturgical Press, Collegeville, PA.

Mitchell, M.M., 2012, 'From Jerusalem to the ends of the Earth', in M.M. Mitchell \& F.M. Young (eds.), The Cambridge history of Christianity: Origins to Constantine, pp. 295-301, Cambridge University Press, New York.

Musurillo, H., 1972, The Acts of the Christian martyrs, viewed 11 February 2017, from https://www.pbs.org/wgbh/pages/frontline/shows/religion/maps/primary/ perpetua.htm

Nickelsburg, G.W.E., 2003, Ancient Judaism and Christian origins: Diversity, continuity and transformation, Fortress Press, Minneapolis, MN.

Oden, T.C., 2011, The African memory of mark: Reassessing Early Church tradition, IVP Academic, Downers Grove, IL.

Phillips, V., 1917, The work of St. Optatus against The Donatists, Oxford University Press, New York.

Phillipson, D.W., 2009a, Ancient Churches of Ethiopia. Fourth-fourteenth centuries, Yale University Press, London.

Phillipson, D.W., 2009b, Aksum, the entrepot, and highland Ethiopia, 3rd-12th centuries, in M. Mango 2009, Byzantine Trade, 4th-12th Centuries: The Archaeology of Local, Regional and International Exchange: Papers of the Thirty-eighth Spring Symposium of Byzantine Studies, St John's College, University of Oxford, March 2004, Volume 14 of Publications of the Society for the Promotion of Byzantine, Volume 14 of Society for the Promotion of Byzantine Studies publications, pp. 353-368. Ashgate Publishing Ltd., London.

Phillipson, D.W., 2012, Foundations of an African civilisation: Aksum \& the Northern Horn 1000 BC-AD 1300, James Currey, New York.

Potter, D., 2013, Constantine the emperor, Oxford University Press, Oxford.

Roldanus, J., 2006, The Church in the age of Constantine: The theological challenges, Routledge, London.

Ruether, R.R., 1996, Faith and Fratricide: The Theological roots of Anti-Semitism, Wipf and Stock Publishers, Eugene, OR.

Salzaman, M.R., 2002, The making of a Christian Aristocracy: Social and religious change in the western Roman Empire, Harvard University Press, Cambridge, MA.

Schaff, P. (ed.), 1885a, Ante-Nicene Fathers. Vol. 1: The Apostolic Fathers with Justin Martyr and Irenaeus, Christian Classics Ethereal Library, Grand Rapids, MI.

Schaff, P. (ed.), 1885b, Ante-Nicene Fathers. Vol. 3: Latin Christianity: Its Founder, Tertullian, Christian Classics Ethereal Library, Grand Rapids, MI.

Schaff, P. (ed.), 1885c, Ante-Nicene fathers. Vol. 5: The fathers of the Third Century: Hippolytus; Cyprian; Caius; Novatian; Appendix, Christian Classics Ethereal Library, Grand Rapids, MI.

Schaff, P., (ed.), 1885d, Nicene and post-Nicene Fathers. Series 2. Vol. 1: Eusebius Pamphilius: Church history, life of Constantine, oration in praise of Constantine, Christian Classics Ethereal Library, Grand Rapids, MI.

Schaff, P., (ed.), 1885e, Nicene and post-Nicene fathers. Series 2. Vol. 2: Socrates and Sozomenus ecclesiastical histories, Christian Classics Ethereal Library, Grand Rapids, MI. 
Schaff, P., (ed.), 1885f, Nicene and post-Nicene fathers. Series 2. Vol. 3: Theodoret, Jerome, Gennadius, \& Rufinus: Historical writings, Christian Classics Ethereal Jerome, Gennadius, \& $\mathrm{R}$ Library, Grand Rapids, MI.

Sider, R.D., 1971, Ancient Rhetoric and the Art of Tertullian, Oxford University Press, London.

Thompson, G.L., 2015, 'Bauer's Early Christian Rome and the development of Orthodoxy', in P.A. Hartog (ed.), Orthodoxy and Heresy in early Christian contexts: Reconsidering the Bauer Thesis, pp. 213-234, Pickwick Publications, Eugene, OR.

Tilley, M.A., 2012, 'North Africa', in M.M. Mitchell \& F.M. Young (eds.), The Cambridge History of Christianity: Origins to Constantine, pp. 485-503, Cambridge University Press, New York.

Van Dam, R., 2011, Remembering Constantine at the Milvian Bridge, Cambridge University Press, New York.
Varner, W., 2015, 'Baur to Bauer and beyond: Early Jewish Christianity and Morden scholarship', in P.A. Hartog (ed.), Orthodoxy and Heresy in Early Christian Contexts: Reconsidering the Bauer Thesis, pp. 89-113, Pickwick Publications, Eugene, OR.

Vermes, G., 2012, Christian beginnings: From Nazareth to Nicaea (AD 30-325), Penguin Group, London.

Wickman, E., 2017, Shaping Church-State relations after Constantine: The political theology of Hilary of Poitiers, Cambridge University Press, Cambridge.

Wilhite, D.E., 2017, Ancient African Christianity: An introduction to a unique context and tradition, Routledge, New York.

Williams, F., 2009, The Panarion of Epiphanius of Salamis Book 1, Sects 1-46, Brill, Leiden.

Yoder, J.H., 2003, The Jewish-Christian Schism revisited, Eerdmans, Grand Rapids, MI. 